\title{
EGY RÖVID ÁTTENKITÉS A TERMOELEKTROMOS ANYAGTUDOMÁNY FEJLŐDÉSRŐL.
}

\section{A SHORT REVIEW OF THE LATEST DEVELOPMENTS IN SCIENCE OF THERMOELECTRIC MATERIALS.}

\author{
Edgar Marcial Pimentel ${ }^{1}$, István Nagy ${ }^{2}$ \\ ${ }^{1}$ Óbuda University, Donát Bánki Faculty of Mechanical and Safety Engineering, \\ Hungary, Budapest, Népszínház Utca, 8; Telefon / Fax: +36-70-222-77-11, Email: \\ edgarmar.pimsev@gmail.com \\ ${ }^{2}$ Óbuda University, Donát Bánki Faculty of Mechanical and Safety Engineering, \\ Hungary, Budapest, Népszínház Utca, 8; Telefon / Fax: +36-1-666-53-66, Email: \\ nagy.istvan@bgk.uni-obuda.hu
}

\begin{abstract}
This research work is still considered as a theoretical reference material for transmitting the important role that thermoelectric materials play in our evolving world's reality. In this update, a brief reminder on the basics behind thermoelectric materials is provided, followed by some of the most recent developments, rather successful or not, in the attempt to create new more efficient materials for heat recovery within next years. One of the approaches deals with an innovative way to produce an already existing base material for thermoelectric application, whilst the other approaches describe new possibilities that were tried out as attempts to reach a higher dimensional figure of merit zT.
\end{abstract}

Keywords: thermoelectric materials, recent research, nano structures, dopping, substitution.

\section{Összefoglalás}

Ez a kutatómunka elméleti referencia anyagnak tekinthető, amely a termoelektromos anyagok fontosságát mutatja be a fejlődő világunkban. Ez a kutatás röviden ismerteti a termoelektromos anyagok mögött álló alapokat, amelyek az aktuális fejlesztéseket követik, amelyek többé-kevésbé sikeresnek tekinthetők, olyan értelemben, hogy az elkövetkező években új, hatékonyabb anyagokat hozzanak létre a hővisszanyerés érdekében. Az egyik megközelítés innovatív módon foglalkozik a már meglévő termoelektromos alkalmazások alapanyagainak előállításával, míg a többi megközelítés olyan új lehetőségeket ír le, amelyeket egy magasabb dimenziójú zT teljesítménytényezőt eredményeznek.

Kulcsszavak: termoelektronikus anyagok, legújabb kutatások, nanostruktúrák, adalékolás, helyettesítés.

\section{Introduction}

Modern society evolves at an exponential rate and as technology develops, the levels of energy consumption keep increasing in a proportional matter.

Materials science has been dealing with these issues since a couple decades in the past and has lead us to this point in actuality where we have come with creative ideas to overcome this problem, thanks to the use of techniques and knowledge areas such as nano-engineering.

In a previous paper, it was described how the potential discovery of sufficiently efficient materials in the field of thermo- 
electrics, could be extremely beneficial for both the industrial and the houseware sectors, saving a good portion of energy that is usually dissipated as heat in most of the daily life procedures.

Just as an example, approximately $40 \%$ of the fuel energy is wasted in exhaust gas, $30 \%$ is dissipated in the engine coolant, $5 \%$ is lost as radiation and friction, and only $25 \%$ is used for vehicle mobility and accessories. [1]

With the previous statement, it could be inferred that from out of the nearly 3042.5 thousand barrels of gasoline consumed in Europe per day [2], only 760.6 are effectively producing motion.

\section{Background}

On the one hand, electric conductivity is that one that allows the flow of charges (holes or electrons) freely through the material at a certain rate, meaning how good would this material conduct electricity, in simple words.

On the other hand, the thermal conductivity is that one that allows the heat phonons to travel acroos the thickess of the material at a certain rate, so, in simple words again, how good would this material disipate heat.

Let us recall also that there is an important factor, called the adimensional figure of merit, defined by the following:

$$
Z T=\frac{S^{2} \sigma T}{K}=\frac{S^{2} \sigma T}{\left(K_{e}+K_{l}\right)}
$$

Where, $\mathrm{S}=$ Seebeck Coefficient, $\mathrm{K}=$ Thermal Conductivity, $\sigma=$ Electrical Conductivity and $\mathrm{T}=$ Absolute Temperature.

As can be seen from the equation above, the Thermal Conductivity is then split into two components, one of which is $K_{e}$ known as the component of it due to the electric conductivity, whilst $K_{l}$ reffers to the component inherent to the lattice estructure itself.

\subsection{Manufacturing Improvements}

SnTe is an important material in the world of thermoelectric materials due to the fact that it is known that some research conducted over the effect that band structure engineering and some similar techniques have over this material regarding the enhancement of its thermoelectric power factor $\left(S^{2} \sigma\right)$; in fact, it is known already that by enhancing phonon scattering on this material, can minimize the thermal conductivity in such a way that the figure of merit $z T$ can range in values from 1.1-1.3 at $823 \mathrm{~K}-873 \mathrm{~K}$ or can go also up to $1.3-1.4$ at 900K-923K.

As a counterpart, for producing the basic SnTe component, it is usually required to use some time-and-energy demanding procedures, however, a research group from several universities in the United Kingdom developed throughout 2017 a new method which consumes less time and energy for sintering this material on volumes above $10 \mathrm{~g}$. per batch.

The method involves the boiling up of an alkaline $\mathrm{Na}_{2} \mathrm{SnO}_{2}$ solution and a NaHTe solution for short time. Then from this aqueous solution, spark plasma sintering is used resulting in nanoparticles that have a comparable thermoelectric performance to their bulk material counterparts. [3]

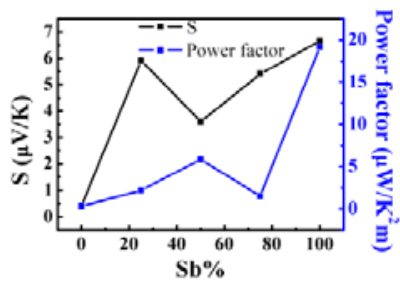

1. Figure. Relative Seebeck coefficient and power factor of the Bi $2-x \mathrm{Sb} \times \mathrm{Te} 3$ NWs plotted as a function of the nominal Sb content in the samples. [4] 
Another of the laboratory approaches that has been made deals with test methods to create and measure $B i_{2-x} S b_{x} T e_{3}$ nanowires grown into nanoporous polycarbonate templates. In the figure below, it can be seen how depending on the $S b$ content of these templates, the thermoelectric power factor and the Seebeck coefficient are affected. [4]

\subsection{New Materials Testing}

One particular case of study that drew attention was that from a research group from Korea in which they proved that substitutional $\mathrm{Pb}$ doping in base $B i_{0.48} S b_{1.52} \mathrm{Te}_{3}$ can actually reduce the $K_{l}$ component of thermal conductivity and simultaneously increase the power factor $S^{2} \sigma$.

For this research, parameters were measured for $\mathrm{Pb}$-dopped material samples $\left(B i_{0.48-x} P b_{x} S b_{0.52} T e_{3}\right.$, at $x=$ $0.0025,0.005,0.01,0.015$ and 0.02 ) and also for undopped base material. [5]

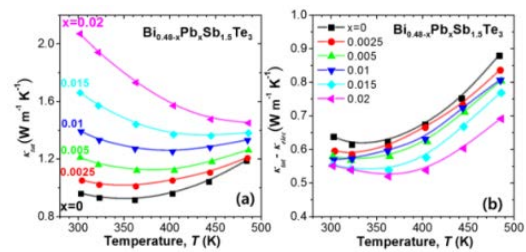

2. Figure. Temperature dependence of (a) total thermal conductivity ( $\kappa$ tot $)$ and (b) $(\kappa$ tot $-\kappa$ elec )(2017). [5]

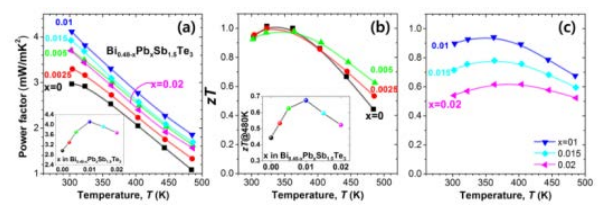

3. Figure. (a) Temperature dependence of power factor $(\sigma S 2)$ Inset shows the power factor value at $300 \mathrm{~K}$ for the samples; $(b, c)$ Temperature dependence of $a$ dimensionless figure of merit, $z T$ (c) $x=$ $0.01,0.015$, and 0.02. Inset in (b) shows the $\mathrm{zT}$ value at $480 \mathrm{~K}$. (2017) [5]
It is plain to see that the bipolar doncution suppression to thermal conductivity reduction increased by $70 \%$.

Finally, in spite of these achievements, it is also noticeable how after all the $z T$ figure of merit is still not as high as desireable for application purposes.

Passing onto the next approach, a different research group has dealt with a similar method to introduce $\mathrm{Cu}$ interstitial substitution dopping. $\mathrm{Cu}$ is to be found at the place of $S b$ for p-type $B i_{0.5} S b_{1.5} T e_{3}$, which allowed to significantly enhance the electric conductivity. Due to nanoestructural defects, it is also possible to reduce both the termal and the bipolar conductivity of the material. Another effect of this substitution is that the hole carrier concentration is enhanced, and as a final result, the figure of merit $z T$ was able to actually go up to 1.4 at around $430 \mathrm{~K}$ temperature, which again represents an increasement comapred to undopped $B i_{0.5} S b_{1.5} T e_{3}$ of around 70\%. [6]

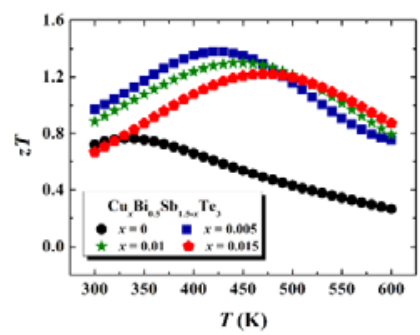

4. Figure. Temperature dependence of figure of merit zT for Cu-doped samples. The data for $x=0$ and $x=0.005$. (2017) [6]

Another approach made by a group in Tokyo, studies the possibilities to use hybrid materials between organic and inorganic base components to create new generation thermoelectric materials.

For their study they created some films based on 3 organic/inorganic components which resulted in a set of nanoPETT/PI/SG-CNT hybrid films. 
The results showed that indeed the power factor improved by the making of these hybrid films with respect to their separate counterparts, however these improvements are not sufficient since the magnitudes of thermoelectric properties are of lower order than regular materials. [7]

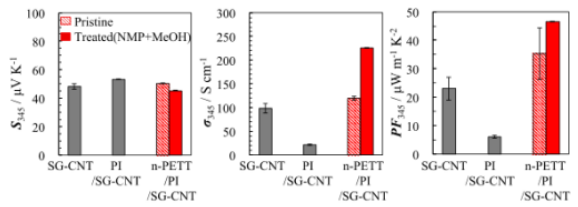

5. Figure. Seebeck coefficient (S), electrical conductivity $(\sigma)$ and power factor (PF) of SG-CNT sheet, PI/SG-CNT and nanoPETT/PI/SG-CNT. All films have a thickness of $10 \mu \mathrm{m}$. (2017) [7]

Last but not least, there was an attempt to utilise $\mathrm{GeTeSe}$ crystals doped by $\mathrm{Cu} / \mathrm{Bi}$ which resulted in materials that showed relative improvements, but not able to surpass a figure of merit value of $z T=$ 0.16. [7]

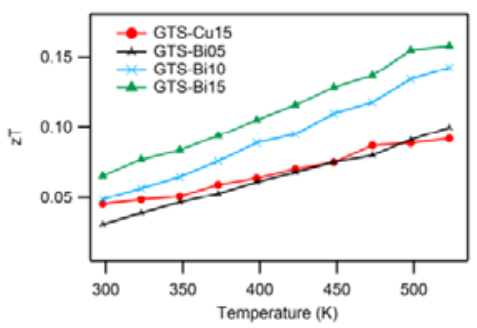

6. Figure. Dimensionless Figure of merit, zT for $\mathrm{Cu}$ - and Bi-doped GTS samples, showing a maximum zT of $\sim 0.16$ for GTS-Bi15 and 0.092 for GTS-Cu15 at 523 K. (2017) [7]

\section{Conclusion}

Throughout this year 2017, some achievements were reached within the area of thermoelectrics, mainly by the application of doping materials to base thermoelectric composites. As for the rest of the areas within this field, some new possibili- ties were open, which will allow us to change our perspective in this crusade in the seek of more efficient materials, regardless of its not so successful current status. Indeed, science has been focusing more day by day within this area and hopefully, given that this rhythm of interest keeps constant or at an exponential growth, the materials we aim to obtain will be ready to manufacture in the term of 5 years from today.

\section{References}

[1] Zhi-Gang C.;Guang H.; Lei Y.; Lina C.; Jin Z: Nanostructured Thermoelectric Materials: Current Research and Future Challenge. Progress in Natural Science: Materials International 22, 2012, 535-549.

[2] Index Mundi: Motor Gasoline Consumption by Country. 2012.

[3] Guang Han; et all.: Large-Scale SurfactantFree Synthesis of p-Type SnTe Nanoparticles for Thermoelectric Applications. Materials - Open Access Materials Science Journal. 2017.

[4] Anuja Datta; Abhijeet Sangle; Nick Hardingham; Charles Cooper; Max Kraan ; David Ritchie; Vijay Narayan; Sohini KarNarayan: Structure and Thermoelectric Properties of Bi $2-x$ Sb $x$ Te 3 Nanowires Grown in Flexible Nanoporous Polycarbonate Templates. Materials - Open Access Materials Science Journal. 2017.

[5] Hyun-sik K.; Kyu Hyoung Lee; Joonyeon Yoo; Jehun Youn; Jong Wook Roh; Sang-il Kim; and Sung Wng Kim: Effect of substitutional $\mathrm{Pb}$ Doping on Bipolar and Lattice Thermal Conductivity in p-Type Bi0.48Sb0.52Te 3. Materials - Open Access Materials Science Journal. 2017.

[6] Feng Hao, et all: Roles of $\mathrm{Cu}$ in the Enhanced Thermoelectric Properties in Bi0.5Sb1.5Te 3. Materials - Open Access Materials Science Journal. 2017.

[7] Keisuke Oshima; Shifumi Sadakata; Hitoshi Asano; Yukihide Shiraishi; Naoki Toshima: Thermostability of Hybrid Thermoelectric Materials Consisting of Poly(Niethenetetrathiolate), Polyimide and Carbon Nanotubes. Materials - Open Access Materials Science Journal. 2017. 